\title{
INOCULATION OF TOMATO SEEDLINGS WITH TRICHODERMA HARZIANUM AND ARBUSCULAR MYCORRHIZAL FUNGI AND THEIR EFFECT ON GROWTH AND CONTROL OF WILT IN TOMATO SEEDLINGS
}

\author{
Margaret W. Mwangi ${ }^{1}$; Ethel O. Monda ${ }^{1}$; Sheila A. Okoth ${ }^{2}$; Joyce M. Jefwa ${ }^{3}$ \\ ${ }^{1}$ Department of Plant and Microbial Sciences, School of Pure and Applied Sciences, Kenyatta University, Box 43844-00100 \\ Nairobi, Kenya; ${ }^{2}$ Department of Botany, School of Biological Sciences, University of Nairobi, Box 30197-001000 Nairobi. \\ Kenya; ${ }^{3}$ CIAT-Nairobi TSBF. Off UN Avenue Gigiri P.O.Box 823- 001621 Nairobi. Kenya.
}

Submitted: November 10, 2009; Returned to authors for corrections: December 14, 2009; Approved: November $04,2010$.

\begin{abstract}
A green house study was conducted to investigate the ability of an isolate of Trichoderma harzianum (P52) and arbuscular mycorrhizal fungi (AMF) in enhancing growth and control of a wilt pathogen caused by Fusarium oxysporum f. sp. lycopersici in tomato seedlings. The plants were grown in plastic pots filled with sterilized soils. There were four treatments applied as follows; P52, AMF, AMF + P52 and a control. A completely randomized design was used and growth measurements and disease assessment taken after 3, 6 and 9 weeks. Treatments that significantly $(\mathrm{P}<0.05)$ enhanced heights and root dry weights were P52, AMF and a treatment with a combination of both P52 and AMF when compared the control. The treatment with both P52 and AMF significantly $(\mathrm{P}<0.05)$ enhanced all growth parameters (heights; shoot and root dry weight) investigated compared to the control. Disease severity was generally lower in tomato plants grown with isolate P52 and AMF fungi either individually or when combined together, though the effect was not statistically significant $(\mathrm{P} \geq 0.05)$. A treatment combination of P52 + AMF had less trend of severity as compared to each individual fungus. T. harzianum and AMF can be used to enhance growth in tomato seedlings.
\end{abstract}

Key words: Arbuscular mycorrhizal Fungi (AMF), Trichoderma harzianum (P52), Disease severity

\section{INTRODUCTION}

Tomatoes are one of the most widely cultivated vegetable crops in Africa. Its fruit is rich in vitamins and is therefore used in salads, cooked as a vegetable or made into tomato paste and tomato sauce. Tomato yields in smallholder cropping systems are generally far below the potential of the crop, due to low quality seeds, poor crop husbandry and pests and diseases (23). In Kenya there was a decrease in total area planted with tomatoes and production of tomatoes between the years 20052006 (15). Total area in hectares reduced from 20,743 to 19,541 , production from 337,447 to 334,478 metric tonnes and 
value from 5.6 billion shillings to 4.9 billion shillings. The major constraints that caused this decline were high prices of inputs, poor crop management practices, transportation, marketing, diseases and pests.

Tomato plants are affected by several diseases, including Fusarium wilt caused by Fusarium oxysporum f. sp. lycopersici (sacc.) Snyder and Hansen. This is a destructive disease of tomato worldwide (14). Methods used to control vascular wilt are either not very efficient or are difficult to apply. The best way to control the disease is by selecting resistant varieties of tomatoes. Although commercial varieties of tomato resistant to F. oxysporum f. sp.lycopersici races 1 and 2 are available, additional pathogenic strains and race 3 of the pathogen has been reported in several countries (2). For this reason, alternative methods of controlling the disease have to be explored inclusive of biological control methods. Adding biocontrol agents directly to the roots is an efficient and inexpensive means to provide a more vigorous transplant with disease protection when it is transplanted in the field (18).

Trichoderma species, that are common inhabitants of the rhizosphere are biological control organisms against a wide range of soil borne pathogens and also have been known to provide plant growth promotion. Trichoderma harzianum Rifai have been known to show antagonism to various root pathogens such as Pythium spp., Rhizoctonia spp. and Fusarium spp. (4, 7). Some strains of T. harzianum establish robust and long lasting colonization of root surfaces penetrating into the epidermis (12). This colonization by $T$. harzianum frequently enhances root growth development, crop productivity and resistance to abiotic stresses through enhancement of mineral absorption.

The Arbuscular mycorrhizal fungi (AMF) can stimulate plant growth especially in soils with low fertility mainly due to improved phosphorous absorption (13, 20). Arbuscular mycorrhizal fungi have been reported to protect plant roots from some root infecting fungi (5) and are therefore potential biological control agents.
This study was carried out to investigate the effects AMF and T. harzianum in enhancing growth and controlling wilt in tomato caused by $F$. oxysporum f. sp. lycopersici.

\section{MATERIALS AND METHODS}

\section{Study site}

The study was centred at Embu region which is one of the commercial agricultural zones of Kenya. Soils from the study site were sampled from farms where tomatoes had previously been grown. The soils were found to have the following chemical characteristics: $\mathrm{pH}$ in $\mathrm{H}_{2} \mathrm{O}=4.2 ; \% \mathrm{~N}=0.35$; $\% \mathrm{C}=3.86 ; \mathrm{K}=0.5 \mathrm{mg} / \mathrm{l} ; \mathrm{Na}=$ trace; CEC in $\mathrm{cmol} \mathrm{c} / \mathrm{kg}=19.4$; phosphorous in PPMP=6.67. The soil from the field was mixed with sand in the ratio 3:1(soil: sand) to improve the soil texture. The soil was then steam sterilized using a soil autoclave at $121^{\circ} \mathrm{C}$ for 3 hours and procedure repeated after a period of one day. The soils were left for a period of one week to allow for escape of volatile poisonous substances produced during process of sterilization. The soil was then put into $500 \mathrm{ml}$ plastic pots and each of these was then enriched with $0.2 \mathrm{~g}$ of Diammonium phosphate fertilizer (DAP). The soil was then used for the growth of tomato seedlings in the green house.

\section{Source of Inoculum}

The AMF inoculum was a mixture containing four different species of the genus Glomus, three of Acaulospora and one of Gigaspora and were obtained from field trap cultures from Embu that had been preserved in a green house at the National Museums of Kenya (NMK). Sterilized sand was added to these field trap cultures in the ratio of 3:1 (sand: field trap culture), to bulk up and improve soil texture. Seeds of Sorghum vulgare Pers. were planted in field trap cultures sand mixture in 1 litre $(13 \mathrm{~cm}$ diameter $)$ plastic pots in the green house. Sorghum vulgare plants were used as trap plants for the multiplication of AMF inoculum. These $S$. vulgare plant cultures were watered daily and green house sanitation 
maintained for purity of cultures for a period of four months. After 4 months all the sorghum plants in the trap cultures were uprooted and their roots cut into small pieces and then mixed up with soil in the pot. These then formed a uniform inoculum consisting of soil, external mycelia and infected root segments and were used to inoculate experimental plants at the rate of 30 g per plant per pot.

The Trichoderma harzianum isolate (P52) had previously been isolated from the Embu sampling site and preserved in the University of Nairobi laboratories. The isolate P52 was cultured on Potato Dextrose Agar (PDA) at $25^{\circ} \mathrm{C}$ for 4 days. The inocula was produced in potato-dextrose broth shake culture at (150rpm) for 1 week at $25{ }^{\circ} \mathrm{C} \pm 2{ }^{0} \mathrm{C}$. The medium in the flasks was seeded with $7 \mathrm{~mm}$ diameter disks of PDA culture of $T$. harzianum . The cultures were filtered through a double layer of sterilized gauze. The root systems of tomato seedlings were washed in tap water then immersed in a conidial suspension $\left(10^{7} \mathrm{ml}^{-1}\right)$ and were then transplanted into $500 \mathrm{ml}$ pots full of sterilized soils.

Fusarium oxysporum f.sp. lycopersici was isolated from diseased tomato plants obtained from Kabete farm that had shown signs of wilting and had a brown discolouration of vascular vessels. The roots were cleaned, and cut into pieces that were $1 \mathrm{~cm}$ long using a sterile blade. The pieces were sterilized using $0.5 \%$ sodium hypochlorite solution for 30 seconds to remove surface contaminants, then rinsed in sterile distilled water and dried using sterile filter paper. The pieces were then plated on Potato Dextrose Agar (PDA) for 7 days at room temperature $\left(22-23^{\circ} \mathrm{C}\right)$. To suppress bacterial contamination, chloramphenicol an antibiotic was added to media at a concentration of $0.5 \mathrm{mg}$ per litre of molten PDA. Colonies with colony morphology of Fusarium were sub cultured for 7 days on (synthetic nutrient agar) SNA. This is media that allows for sporulation of Fusarium. A portion of mycelia was picked and stained with lactophenol and the fungus identified according Nelson et al. (17). An agar block of the pathogen was preserved on PDA in universal bottle at $4^{0} \mathrm{C}$.
The pathogenicity of the isolate was confirmed by inoculating healthy 28 day old tomato seedlings cultivar Cal-j grown in sterile sand. The seedlings showed symptoms of fusarium wilt disease within 32 days. The fungus reisolated from the seedlings was of similar morphology to the initial fungus used as inoculum. Inocula of $F$. oxysporum f. sp. lycopersici was prepared in a similar manner to that of $T$. harzianum. The sterilized soils in the $500 \mathrm{ml}$ plastic pots were infested with this isolate of Fusarium at a concentration of $10^{7}$ conidia $\mathrm{ml}^{-1}$ of the substrate and was allowed to establish in the soil for a period of 6 days.

\section{Effect of T. harzianum and AMF on growth and disease control of fusarium wilt of tomato}

Certified tomato seeds of cultivar Cal-j were surface sterilized in $1 \%$ solution of sodium hypochlorite for $30 \mathrm{sec}$ and rinsed thoroughly with several changes of distilled water and then dried with sterile blotting paper. The seeds were then germinated in $15 \times 20 \times 10 \mathrm{~cm}$ trays containing sterilized sand. Twenty eight day old tomato seedlings were transplanted into $500 \mathrm{ml}$ (9 $\mathrm{cm}$ diameter) plastic pots, at the rate of one plant per pot in the sterilized field soils already infested with the pathogen. There were four treatments applied as follows; $T$. harzianum isolate P52, AMF (Arbuscular mycorrhizal fungi), $\mathrm{AMF}+\mathrm{P} 52$ and a control (contained only the pathogen $F$. oxysporum f. sp. lycopersici). Each treatment was replicated 24 times and placed in the green house in a completely randomized design. Plants were watered daily and green house sanitation maintained. The green house had temperatures in the range of $20^{\circ} \mathrm{C}$ to $28^{\circ} \mathrm{C}$.

After 3, 6 and 9 weeks height, shoot and root dry weights were determined. Each time four seedlings from each treatment were harvested at random. Shoots height was taken from the base of the stem to the apex. The shoots and the roots were dried in an oven at $70^{\circ} \mathrm{C}$ until constant weight. They were then weighed separately and the weights recorded.

Disease Severity(DS) assessment was done 21 days after 
transplanting when symptoms of infection were observed. Such symptoms included clearing of the veins and drooping of petioles followed by yellowing of lower leaves (1). Four plants were selected at random marked with pieces of string and were used to evaluate disease severity after every 3 weeks. Wilt severity was determined using a modification of a scale by Waudo et al. (24). This was based on the wilt severity rated as follows; ( $\%$ of shoot wilted, using a scale of $0-5$ where, $0=$ No symptoms, $1=$ One leaf wilted $(1 \%-25 \%), 2=2$ or 3 leaves wilted $(26 \%-49 \%), 3=$ half plant wilted $(50 \%-74 \%), 4=$ all leaves wilted (75\%-100\%), 5=Plant dead). Four seedlings from treatments with AMF had their roots stained by method of Kormaik and McGraw (16) and root colonization determined by the Grid Line Intersect Method (11).

\section{Statistical analysis}

Data obtained were analyzed by Analysis of variance (ANOVA) using a statistical package (Minitab 13.1) by one way ANOVA. Treatment mean (dry weights and heights) were separated by Tukeys tests at $5 \%$ level of significance.

\section{RESULTS AND DISCUSSION}

\section{Effect of treatments on growth and wilt pathogen control}

The AMF applied singly enhanced heights and dry root weights significantly $(\mathrm{P}<0.05)$ compared to the control (Table 1 and 3). Observed significant $(\mathrm{P}<0.05)$ growth due to mycorrhizal infection in tomatoes confirms other reports that AMF symbiosis with host plant has an improved growth effect
$(10,22)$. Increased growth due to mycorrhizal infection is mainly attributed to improved phosphorous and micronutrient uptake in the host plant $(13,20)$.

The fungus P52 when applied singly enhanced height and dry root weights significantly $(\mathrm{P}<0.05)$ compared to the control (Table 1 and 3). These results agree with those of Ozbay and Newman (19) where T. harzianum strains were also reported to have significantly $(\mathrm{P}<0.05)$ increased the height, shoot and root dry weight in tomato seedlings transplanted into pots in the green house. There are reports that $T$. harzianum increases the solubility of phosphates and micronutrients such as zinc, copper, iron and manganese all plant nutrients with low solubility(3) and this enhances growth of the roots and the above ground parts of the plant. The treatment with a combination of the two fungi (P52 and AMF) also significantly $(\mathrm{P}<0.05)$ enhanced growth compared to the control in the height; shoot and root dry weights (Table 1, 2 and 3). This treatment with both AMF and P52 enhanced the height significantly over the control by $33.08 \%, 10.54 \%$ and $26.58 \%$ after 6,9 and 12 weeks respectively; while the shoot dry weights were by the rates of $23.26 \%, 76.84 \% .56 .06 \%$ and the root dry weights by $42.86 \%, 40 \%$ and $109.09 \%$. Dual inoculation with $T$. harzianum and AMF has previously been reported to significantly enhance growth more than if each fungus was inoculated singly $(10,22)$. Possibly the $T$. harzianum could have made the phosphorous and micronutrients more soluble (3) while the mycorrhizae enhanced its uptake (20).

Table 1. Effect of treatments on Disease Severity (DS); mean height; shoot and root dry weight after 3 weeks

\begin{tabular}{lllll}
\hline Treatment & Height $(\mathbf{c m})$ & DSW $(\mathbf{g})$ & DRW $(\mathbf{g})$ & DS \\
\hline Control & $20.1 \mathrm{c}$ & $0.86 \mathrm{~b}$ & $0.21 \mathrm{~b}$ & $1.5 \mathrm{a}$ \\
AMF & $21.45 \mathrm{~b}$ & $0.95 \mathrm{ab}$ & $0.28 \mathrm{a}$ & $1.25 \mathrm{a}$ \\
P52 & $23.28 \mathrm{~b}$ & $0.92 \mathrm{ab}$ & $0.32 \mathrm{a}$ & $1.25 \mathrm{a}$ \\
P52+AMF & $26.75 \mathrm{a}$ & $1.06 \mathrm{a}$ & $0.30 \mathrm{a}$ & $1.25 \mathrm{a}$ \\
\hline
\end{tabular}

Data are means of 4 replicates. Means followed by the same letter in the same column are not significantly (Tukey, $\mathrm{P} \geq 0.05)$ different 
Table 2. Effect of treatments on Disease Severity (DS); mean height; shoot and root dry weight after 6 weeks

\begin{tabular}{lllll}
\hline Treatment & Heights $(\mathbf{c m})$ & DSW & DRW & DS \\
\hline Control & $44.4 \mathrm{c}$ & $0.95 \mathrm{~b}$ & $0.35 \mathrm{~b}$ & $3.0 \mathrm{a}$ \\
AMF & $45.28 \mathrm{~b}$ & $0.99 \mathrm{~b}$ & $0.38 \mathrm{~b}$ & $2.5 \mathrm{a}$ \\
P52 & $47.48 \mathrm{~b}$ & $0.99 \mathrm{~b}$ & $0.39 \mathrm{~b}$ & $2.75 \mathrm{a}$ \\
P52+AMF & $49.08 \mathrm{a}$ & $1.68 \mathrm{a}$ & $0.49 \mathrm{a}$ & $2.25 \mathrm{a}$ \\
\hline Data are means of 4 replicates. Means followed by the same letter in the same column are not significantly (Tukey, P $\geq 0.05$ ) different
\end{tabular}

Table 3. Effect of treatments on Disease Severity (DS); mean height; shoot and root dry weight after 9 weeks

\begin{tabular}{lllll}
\hline Treatment & Heights $(\mathbf{c m})$ & DSW & DRW & DS \\
\hline Control & $47.48 \mathrm{c}$ & $0.66 \mathrm{~b}$ & $033 \mathrm{c}$ & $4 \mathrm{a}$ \\
AMF & $55.3 \mathrm{~b}$ & $0.73 \mathrm{~b}$ & $0.47 \mathrm{~b}$ & $3.5 \mathrm{a}$ \\
P52 & $59.9 \mathrm{a}$ & $0.75 \mathrm{~b}$ & $0.48 \mathrm{~b}$ & $3.75 \mathrm{a}$ \\
P52+AMF & $60.1 \mathrm{a}$ & $1.03 \mathrm{a}$ & $0.69 \mathrm{a}$ & $3.25 \mathrm{a}$ \\
\hline
\end{tabular}

Data are means of 4 replicates. Means followed by the same letter in the same column are not significantly (Tukey, $\mathrm{P} \geq 0.05)$ different

Individually the biocontrol fungus P52 and AMF lowered disease severity as compared to the control experiment where the biocontrol fungi had not been added. A combination of P52 and AMF had less trend of severity of disease. There was however no significant differences in lowering disease severity by the treatments ( $\mathrm{P} \geq 05$, Tables 1,2 and 3$)$. In an experiment where commercial formulations of AMF and T. harzianum were applied to control fusarium wilt and rot disease, each of the fungi showed significant disease control but better results were obtained when both agents were used together (8). The ability of T. harzianum to control plant pathogens is considered to be a result of several mechanisms including mycoparasitism and induction of systematic defense mechanism $(6,25)$. On the other hand AMF has been known to increase plant resistance to infection through improved plant nutrition (9)

AMF treatment had $65.1 \%$ of the root length colonized by AMF with a Standard Deviation (SD) of $7.1 \%$. A treatment with both P52 and AMF had 73.2\% (SD 8.3\%) of root length colonized by AMF. A comparison of mycorrhizal colonization in the treatment AMF and treatment with both AMF and P52 showed that they were not significantly $(\mathrm{P} \geq 05)$ different. $T$. harzianum showed compatibility with AMF and no inhibitory effects on the development of mycorrhizal colonization was observed. This concurs with an experiment where $T$. harzianum did not affect colonization by AMF in three balcony plants (Verbena, Torenia, Diascia) inoculated with both AMF and T. harzianum (22). Nevertheless contrary reports of reduction in colonization in AMF by T. harzianum have previously been reported (21).

Considering the immense importance of tomatoes and the threat caused by Fusarium wilt and resistance to commonly used fungicides; biocontrol methods can be an option for disease control and growth enhancement. Interest in the ability of beneficial microorganisms to control diseases has grown, particularly with respect to their being environmentally friendly. Dual inoculation of tomato seedlings with $T$. harzianum and $\mathrm{AMF}$ is recommended as it significantly enhances growth. An increase in the concentration of fungal inoculum used might eventually lead to better disease control. 


\section{ACKNOWLEDGEMENTS}

This work was supported by the Below- Ground Biodiversity project with co-financing from Global Environmental Facility (GEF) and UNEP (United Nations Environmental Programme).

\section{REFERENCES}

1. Agrios, G.N. (1988). Plant Pathology. Third Ed. Academic Press, New york.

2. Amini, J. (2009). Physiological race of Fusarium oxysporum f. sp. lycopersici in Kurdistan province of Iran and reaction of some tomato cultivars to race 1 of pathogen. Plant Pathol. J. 8, 68-73.

3. Altomare, C.; Norvell, W.A.; Bjorkman, T.; Harman, G.E. (1999). Solubilization of phosphates and micronutrients by plant growth promoting and biocontrol fungus Trichoderma harzianum strain 129522. Appl. Environ. Microbiol. 65, 2926-2933.

4. Baker, R. (1989). Improved Trichoderma spp. for promoting crop productivity. Trends Biotechnol. 7, 34-38.

5. Caron, M. (1989). Potential use of mycorrhizae in soil borne diseases. $C$. J. Plant Pathol. 11, 177-179.

6. Chet, I. (1987). Trichoderma-application, mode of action, and potential as biocontrol agent of soilborne plant pathogenic fungi. In Chet, I. (eds). Innovative approaches to plant disease control. John Wiley and Sons, Inc. New york.p.137-160.

7. Chet, I.; Elad, Y.; Sadowsky, Z. (1987). Scanning electron microscopical observations of early stages of interaction of Trichoderma harzianum and Rhizoctania solani. Trans. Br. Mycol. Soc. 88, 257-263.

8. Datnoff, L.E.; Nemec, S.; Pernezny, K. (1995). Biological control of Fusarium crown and root rot of tomato in Florida using T. harzianum and Glomus intraradices. Biol. Control. 5, 427-431.

9. Declerck, S.; Risede, J.M.; Rufyikiri, G.; Delvaux, B. (2002). Effect of arbuscular mycorrhizal fungi on severity of root rot of bananas caused by Cylindrocladium spathiphylli. Plant Pathol. 51,109-115.

10. Dubsk'y, M.; Sr'amek, M.; Vos'atka, M. (2002). Inoculation of Cyclamen (Cyclamen persicum) and Euphorbia pulcherrina with arbuscular mycorrhizal fungi and Trichoderma harzianum. Rostl. Vyroba. 48, 6368.

11. Giovannetti, M.; Mosse, B. (1980). An evaluation of techniques to measure VA infection in roots New Phytol. 84, 489-500.

12. Harman, G.E. (2000). Myths and dogmas of biocontrol. Changes in perceptions derived from research on Trichoderma harzianum T-22. Plant Dis. 84, 377-393.

13. Johnson, C.R.; Menge, J.A.; Schwab, S.; Ting, I.P. (1982). Interaction of photoperiod and vesicular arbuscular mycorrhizae on growth and metabolism of sweet orange. New Phytol. 90, 665-670.

14. Jones, J.B.; Jones, J.P.; Stall, R.E.; Zitter, T.A. (1991). Compedium of Tomato Diseases. American Phytopathological Society St. Paul.

15. Kenya Ministry of Agriculture (2006). Horticultural Division Annual Report. p. 26-27.

16. Kormaik, P.P.; McGraw, A.C. (1982). Quantification of vesicular arbuscular mycorrhizae in plant roots. In: Schenick, N. C. (eds). Methods and principles of mycorrhizal research. American Phytopathological Society St. Paul. p.37-45.

17. Nelson, P.E.; Toussoun, T.A.; Marascs, W.F.O. (1983). Fusarium species. An illustrated manual for identification. Pennsylvania State University. University Press, Pennsylvania.

18. Nemec, S.; Datnoff, L.E.; Strandberg, J. (1996). Efficacy of biocontrol agents in planting mixes to colonize plants and control root diseases of vegetables and citrus. Crop Prot. 15, 735-742.

19. Ozbay, N.; Newman, E.S. (2004). Effect of T. harzianum strains to colonize tomato roots and improve transplant growth. Pak. J. Biol. Sci. 7, 253-257.

20. Smith, S.E.; John, J.B.; Smith, F.A.; Bromley, J.L. (1986). Effect of mycorrhizal infection on plant growth, nitrogen and phosphorous nutrition in glass house grown Allium cepa L. New Phytol. 103, 359373.

21. Sosa, R.; Sanchez, N.; Morales, G. (2006).Arbuscular mycorrhizaeTrichoderma harzianum interaction and effects on Brachiaria decumbens growth. Acta. Biol. Colomb. 11, 43-54.

22. Sr'amek, F.; Dubsk'y, M.; Vos'atka,, M. (2000). Effect of and T. harzianum on three species of balcony plants. Rostl. vyroba. 46, $127-$ 131 .

23. Varela, A.M.; Seif, A.; Lohr, B. (2003). A guide to Integrated Pest Management (IPM) in Tomato Production in Eastern and Southern Africa. ICIPE Science Press, Nairobi.

24. Waudo, S.W.; Owino, P. O.; Kuria, M. (1995). Control of Fusarium wilt of tomatoes using soil amendments. East Afr. Agric. For. J. 60, 207-217.

25. Yedida, I.; Benhamou, N.; Chet, I. (1999). Induction of defense response in cucumber plants (Cucumis sativus L.) by the biocontrol agent Trichoderma harzianum. Appl. Environ. Microbiol. 65, 1061-1070. 